\title{
RESPONSE
}

\section{Failed Reform, Found Resistance: Reflections on Prisons, Abolition and Residential Schools Chris Clarkson and Melissa Munn}

$\mathrm{P}$ risons defy meaningful reform. Born of humanitarian and hierarchical impulses, conceived as controlled experiments in closed environments, designed to forcibly change human personalities through discipline and punishment, modern prisons have failed to meet their stated objectives for over 200 years (Christie, 2000). ${ }^{1}$ Yet they endure. As many of the articles in this issue make clear, prisons in Canada and the United States remain brutal places, coupling deplorable physical conditions with dehumanizing policies and practices (see Vivar, 2014; Shook, 2014, Lashauy, 2014; Hartman, 2014; Jones, 2014). With good reason, several of the authors advocate penal reform, calling for policy alterations or discussing their experience of new initiatives (see Fisher, 2014; Taylor, 2014; Shah, 2014). But reform is destined to fail. It is one element in an enduring cycle of observation, analysis, advocacy, policy modification, flawed or partial implementation, failure, and reversal. This is a pattern noted frequently in the literature and at various points in this issue. ${ }^{2}$ For generations, thoughtful and compassionate people have studied the problems of penal systems and recommended reform. In Canada, for example, Royal Commissions, parliamentary committees, task forces, prison administrators, and reformers of various persuasions have clearly recognized the problems inherent in imprisonment. These investigators identified serious problems, often shocked the public with their reports, and recommended changes to prison architecture, policies governing the treatment of prisoners, and rehabilitative programming (e.g. Jackson, 1983, pp. 28-31; Crowley, 1990, pp. 130-146; Withrow, 1933; Canada, 1938; Gibson, 1947; Canada, 1956; Canada, 1969; CSC, 1990).

Every reform movement provides its own optimistic blueprint for the prison of the future. Every investigation and every proposal seduces the public with the promise that prisons need not be oppressive, and that they could be, with the right recipe, kinder, gentler reformatories. In a perverse irony, the reform vision upholds the prison as the key to liberating the captive. In the humanizing prison, the transformative prison, the prisonas-community, the prisoner is readied for release. Ultimately, the reformers 
promise a functional prison: a prison that serves both society's and the prisoners' needs. And yet, the result is a legacy of dysfunction and failure. The prison does reshape personalities, but as Jerry Lashuay's (2014) story makes clear, it does so in destructive ways; ${ }^{3}$ and, as both he and Forrest Lee Jones (2014) emphasize, the authorities knowingly neglect prisoners in their care. ${ }^{4}$ As a result, in each case, within a couple of decades, a new commission and new generations of prison reformers repeat the same or largely similar concerns, and advocate another round of reform. ${ }^{5}$ Stanley Cohen's (1985) now classic analysis offers two alternative interpretations of this cycle of penal practice and reform. The first interpretation is that the penal system was devised with good intentions, which are undermined by managerial and pragmatic concerns during implementation (ibid, p. 21). In this case, reform is a reasonable response. It is an effort to redirect the system back to its proper, socially necessary and humanitarian purpose. The second interpretation holds that the penal system is one facet of a larger socio-political project to "make acceptable the exercise of otherwise unacceptable power" (ibid, p. 22). In this view, the prison is one institution among a constellation of state agencies and institutions created to enshrine domination by a particular category of persons through regulation based on classification such as class, race, and gender (also see Corrigan and Sayer, 1985; Curtis, 1992, pp. 9-10). In this analysis, the entire purpose of the institution is unsupportable, which no amount of reform can correct.

At one level, reform has a certain undeniable logic. It is a reasonable response to work from an existing situation, especially when confronted with a massive complex of issues that seem too large to be addressed simultaneously or when certain aspects of a problem appear particularly pressing. Reform lends itself to partial, incremental change. Reform is also appealing when no ready-made, drop-in alternative solution is available. It generally demands no new, paradigm-shifting premise. In his journal, in his immediate effort to come to terms with the death of a prisoner in custody, Jarrod Shook (2014, p. 16) calls for "architectural changes, cultural change, and changes in the way CSC approaches intervening in the lives of those it assumes responsibility for". Yet on reflection, in his conclusion, Shook wonders if prisons are "perhaps worthy of being abolished altogether" (ibid, p. 19). The latter is the approach advocated by ICOPA, an approach that has itself shifted over time. As Bob Gaucher explains, early in its history, ICOPA moved from prison abolition to a "broader focus, relocating the 
analysis of the prison within the complex social structures, social relations and social control institutions of western societies; that is, 'penal' abolition" (Gaucher, 2013, p. 130). Shook (2014, p. 12) accurately captures the reason for this approach early in his narrative: while prisons have been subject to reform and have evolved over time, the underlying structural brutalities remain. It's "business as usual". Moreover, as Kenneth Hartman's (2014, pp. 35-37) piece on life without the possibility of parole makes plain, reforms often produce an entirely new set of negative consequences. In the end, we should not settle for prettier prisons or "subtle and somewhat less perceptible" brutality (Shook, 2014, p. 13). Nor should we settle for another round of failure. We must insist upon the elimination of the entire disciplinary, punitive approach, and its commitment to reproducing social and political hierarchies.

The enormous challenge of penal abolition can be daunting. It is hard to imagine a prisonless society. It is perhaps even more difficult to imagine a society without punishment as a core organizing principle. But if history teaches us anything, it is that social orders are in no way 'natural'. Societies are the accumulated product of generations of decisions, conflict, compromise and contingency. The social order that we have today was not the only possibility. It was one of a range of possibilities and we know that societies can take an extremely wide variety of forms without collapsing. Change is both possible and realistic.

Crucially, we have, in Canada and elsewhere, a model for the abolition of a carceral institution. It can be and has been done. From the 1960s onward, the Canadian government dismantled the residential school system imposed on indigenous peoples. The similarities between the institutions are both striking and telling, and include a combination of involuntary incarceration, forced change, brutality, and dehumanization. ${ }^{6}$ The parallels in the histories of prisons and residential schools, and in the experiences of prisoners and residential school survivors are many: disorientation upon entry; ritualized status degradation ceremonies; the dehumanizing hierarchies of institutional relationships; ${ }^{7}$ the roles of work and religion as transformative agents (see McCoy, 2012, pp. 9, 13-14; Miller, 1995, pp. 102, 252); the production of institutionalized personalities (see Rotman, 1995, pp. 170-171; Miller, 1995, p. 387); the emotional scars that transcend 'release'; the far-reaching impact upon families and communities (see Haig-Brown, 1988, pp. 43, 7987, 104-114; Canada, 1956, pp. 70-71; Canada, 1969, pp. 377-378); and the 
closely coinciding administrative concerns, ${ }^{8}$ barely scratches the surface of the overlap in these two total institutions.

Today, most Canadians would consider it absurd to debate the merits of residential schools or the ways in which those institutions might have been reformed into kinder, gentler vehicles for the assimilation of indigenous people. There is a consensus that the underlying purpose of these institutions was unsupportable. Yet many Canadians are perfectly comfortable with the methods and purposes of prisons, and some support even more severe policies and institutions. As abolitionists, we need to convince the public that the underlying purpose of prisons - like that of residential schools - is unsupportable. Perhaps we can find a way forward in the history of the residential schools and their closure.

Most importantly for our purposes, we must recall that residential schools were closed or transferred to indigenous control as the result of political action. Indigenous people across Canada mounted localized resistance to residential schooling for decades, as individuals and as communities, through non-cooperation, confrontation, formal petitions and litigation. But the successful campaign to establish indigenous control over education came after First Nations leaders organized, first provincially, and then nationally. Those indigenous leaders, including many who had attended residential schools, worked with supportive non-indigenous community groups, academics, and even sympathetic administrators in the Department of Indian Affairs, to make it clear to the Canadian public and the federal government that the residential school system was a failure, and that decisive change to educational policy was their highest priority (see Milloy, 1999, pp. 190, 236; Miller, 1996, pp. 343-405). It is worth noting that when change ultimately came, it was facilitated by a changed socio-political climate and new governmental priorities. The importance of post-war opposition to racism, the challenges to constituted authority posed by civil rights, anti-war, feminist, and student movements around the world, the growing indigenous population, and a federal government keen to simultaneously curb costs and win political support by integrating indigenous children into the provincial public school systems should not be overlooked (Miller, 1996, pp. 382-383, 399). ${ }^{9}$

What lessons should penal abolitionists draw from that experience? If change is possible, what is the way forward? For ICOPA, one point of note is that race (and racism) is a key means of producing what Philip Abrams 
(1988, p. 63) terms "politically organized subjection". The abolition of residential schools depended on the (still incomplete) discrediting of a racist ideology. ICOPA needs to continue to engage in introspection, and continue to ask and address the very difficult questions that emerged during the 2014 conference. Debates over discrimination based on race, class, and gender are needed in critical socio-political movements. Penal abolition is a struggle to resist and change a toxic system dedicated to maintaining hierarchies of power by imposing discipline and subjection on particular categories of people, and by gaining the collaboration of others through status recognition and material inducements. ${ }^{10}$ If we fail to ask the difficult questions and address them, we risk making ICOPA an equally toxic milieu, reflective of the broader social order. ${ }^{11}$ It is incumbent upon us to work continually to ensure that ICOPA does not dehumanize or degrade any of its participants, and that we address inequities based on privilege. ICOPA must not have a "permanent underclass" (Nagelsen and Huckelbury, 2014, p. 53).

The struggles of indigenous peoples against colonial oppression also reinforce the importance of subject involvement in and leadership of resistance movements. Prisoner participation and leadership is important to ICOPA because prisoners have experience and expertise with regard to the penal system that those of us 'on the outside' simply cannot have. Prisoners bring important perspectives on key issues. For example, consider the debates over race at ICOPA 2014 (and the ones which preceded it) and the simplicity with which Jarrod Shook (2014, p. 12) acknowledges his racial privilege and its results. Likewise, Kenneth Hartman's (2014) position on life without the possibility of parole resonates because it is presented by the sufferer in such powerful terms. It could not have the same impact if made by an outsider. As feminist activists have long known, that personal impact is important - it grounds us. ICOPA needs prisoner leadership because it is by coming to terms with prisoners as human beings that the public will become receptive to change. As was the case with indigenous leaders and residential schools, the public needs to 'know' and come to identify with the subject of oppression in order for change to occur. ${ }^{12}$

While prisoners have much to offer ICOPA, the reverse is also true. ICOPA can offer something to prisoners and can do so in the near term. Consider "Chester Abbotsbury's" (2014, p. 28) statement that "the sad thing is that the person inside the fortress starves for human contact", or the despondency of Kenneth Hartman's (2014, p. 46) observation that "prisoners sentenced to a slow 
death by imprisonment are daily reminded that their lives are simply not that important". The penal abolition movement can provide something of value for prisoners right now - inclusion, connection, and meaning - as well as in the long term, if ICOPA involves them meaningfully and avoids the trap of becoming a movement of academics and activists. Building those relationships can be difficult and emotionally exhausting. ${ }^{13}$ We need to rise to the challenge. Indeed, the residential school experience - and the history of indigenous activism shows the crucial support that 'outside' activists and academics can provide.

Finally, the residential school experience is important because it confirms that the struggle is not over when the institutions close. As previously noted, early in its history, ICOPA expanded its focus from prison abolition to resisting a society based on penality. Residential schools for indigenous children closed over four decades ago in most parts of Canada. Yet the enduring legacy of the schools, and the values that produced them, persists. As Neil Shah (2014, pp. 35-36) makes painfully clear in his piece on restorative justice, 'closure' is a difficult object to achieve. There remain scarred residential school survivors who require support. There is an ongoing cycle of abuse with which to contend (Furniss, 1995, p. 31). Racist beliefs and attitudes continue to impact the lives and opportunities of indigenous people. First Nations leaders continue to struggle for recognition of aboriginal and treaty rights. Likewise, even when we succeed in abolishing prisons, we will still need to support former prisoners, their families, their victims, and their communities; and we will still have to contest penality in its other forms. This task, as those who do the writing for the JPP and the work for ICOPA can attest, is massive. It requires deep moral contemplation and strategic action. But the alternative, as Nils Christie (2007) reminds us, is to be complicit in the delivery of pain.

\section{ENDNOTES}

1 Nils Christie contends that contemporary prisons instead meet the unstated goals of supporting the economy through an expansive prison industry.

2 Michel Foucault (1995, p. 268), observing that criticism of the penitentiary emerged almost immediately after its creation, wrote "[t]he answer to these criticisms was invariably the same: the reintroduction of the invariable principles of penitentiary technique. For a century and a half the prison had always been offered as its own remedy". For an analogous interpretation, see Michael Ignatieff (1978. P. 209), Shook (2014, p. 12), Jones (2014, pp. 68-69), and Nagelsen and Huckelbury (2014, pp. 59-60).

As Erving Goffman (1961, p. 71) explains, "[t]otal institutions frequently claim to be concerned with rehabilitation, that is, with resetting the inmate's self-regulatory 
mechanisms so that after he leaves he will maintain the standards of the establishment of his own accord... In fact, this claim of change is seldom realized, and, even when permanent alteration occurs, the changes are often not of the kind intended by the staff'.

4 Lashuay(2014,p.43)writesthat "MichiganDepartment ofCorrectionsprofessionals... understood that children housed within penal facilities are at greater risk than adults. They also understood that their solution to the problem, a protecting housing environment, was not adequate to safeguard these children". Jones (2014, p. 64) describes a similar disregard for prisoner health and safety at a statewide level in California, where Governor Jerry Brown has delayed the implementation of measures to reduce prison crowding, despite a Supreme Court ruling mandating the reduction of prison populations on the grounds that the state is unable to provide adequate medical care.

5 A striking example of the persistence of poor prison conditions can be found in Jose Vivar's (2014) account of Ontario's provincial prisons. Vivar echoes many concerns expressed in the Ouimet Commission report of 1969 (see Canada, 1969, pp. 99-102).

6 The close similarities of the two institutions were noted by those who had been both students and prisoners (Miller, 1996, p. 387). In 1963, social worker Gloria Webster told the United Church Observer, "I used to work with female offenders in Oakalla [prison] and was surprised at the number of Indian girls who would say how similar the prison was to school, only the food was better in prison" (ibid, p. 529).

7 On these points, compare Oswald Withrow's (1933) account of his reception at Kingston Penitentiary in the 1920 s with the experience of indigenous children at the Kamloops Indian Residential School between the 1920s and 1960s (see HaigBrown, 1988, pp. 45-52).

8 Note, for example, the Department of Indian Affairs' focus on vocational training, post-release adjustment, and after-care, described in Miller (1996, pp. 385, 387388). Similar concerns are outlined, for example, in the report by Gibson (1947, pp. 6, 16-17).

9 It is important to note that these facilitative conditions were not determinative. Indigenous political action in Canada preceded the challenges to authority that emerged elsewhere in the late 1950s and through the 1960s. In addition, while the federal government sought integration, many First Nations groups fought for, and secured control over their children's education.

10 For a discussion of status and inducements, see Braverman (1988, pp. 281-282).

11 On the concept of a 'toxic milieu', see Shook (2014, p. 13).

12 Harriet Beecher Stowe's portrayal of slaves in the antebellum South, Uncle Tom's Cabin, provides an example of the radicalizing impact of personal identification with the oppressed. Readers' empathy for Stowe's fictionalized characters - who were based on her experience in Kentucky and with runaway slaves - was instrumental in building abolitionist sentiment in the Northern states. As James McPherson (1988, p. 89) has written, Stowe "aimed the novel at the evangelical conscience of the North. And she hit her mark".

13 Note "Chester Abbotsbury's" (2014, p. 25) explanation that many prisoners had been "shunted aside," having been seen as "requir[ing] too much work" along with his admission that both he and prison staff found it emotionally exhausting to form relationships with prisoners. 


\section{REFERENCES}

Abbotsbury, Chester (2014) "What's In a Name? Depersonalization at the Hands of the State", Journal of Prisoners on Prisons, 23(2): 23-31.

Abrams, Philip (1988) "Notes on the Difficulty of Studying the State", Journal of Historical Sociology, 1(1): 58-89.

Braverman, Harry (1988) Labor and Monopoly Capital: The Degradation of Work in the Twentieth Century $-25^{\text {th }}$ Anniversary Edition, New York: Monthly Review Press.

Canada (1969) Report of the Canadian Committee on Corrections. Toward Unity: Criminal Justice and Corrections, Ottawa: Queen's Printer.

Canada (1956) Report of a Committee Appointed to Inquire into the Principles and Procedures Followed in the Remission Service of the Department of Justice of Canada, Ottawa: Queen's Printer.

Canada (1938) Report of the Royal Commission to Investigate the Penal System of Canada, Ottawa: King's Printer.

Christie, Nils (2007) Limits to Pain: The Role of Punishment in Penal Policy, Eugene (OR): Wipf and Stock Publishers.

Christie, Nils (2000) Crime Control as Industry: Towards Gulags, Western Style (third edition), London: Routledge.

Cohen, Stanley (1985) Visions of Social Control: Crime, Punishment and Classification, Cambridge: Polity Press.

Correctional Service of Canada (1990) Creating Choices: The Report of the Task Force on Federally Sentenced Women, Ottawa.

Corrigan, Philip and Derek Sayer (1985) The Great Arch: English State Formation as Cultural Revolution, Oxford: Basil Blackwell.

Crowley, Terry (1990) Agnes Macphail and the Politics of Equality, Toronto: J. Lorimer.

Curtis, Bruce (1992) True Government by Choice Men: Inspection, Education, and State Formation in Canada West, Toronto: University of Toronto Press.

Fisher, Shawn (2014) "Mass Incarceration: The Further Compromise of Public Safety", Journal of Prisoners on Prisons, 23(2):71-83.

Foucault, Michel (1995) Discipline and Punish: The Birth of the Prison (second edition), New York: Vintage Books.

Furniss, Elizabeth (1995) Victims of Benevolence: The Dark Legacy of the Williams Lake Residential School, Vancouver: Arsenal Pulp Press.

Gaucher, Bob (2013) 'Reflecting on 25 Years of the Journal of Prisoners on Prisons", Journal of Prisoners on Prisons, 22(2): 128-137.

Gibson, R. B. (1947) Report of General R.B. Gibson, A Commissioner appointed under Order in Council P. C. 1313, regarding the Penitentiary System of Canada, Ottawa.

Goffman, Erving (1961) Asylums: Essays on the Social Situation of Mental Patients and Other Inmates, New York: Anchor Books.

Haig-Brown, Celia (1988) Resistance and Renewal: Surviving the Indian Residential School, Vancouver: Tillacum Library.

Hartman, Kenneth (2014) "The Unintended Consequences of Bad Deals", Journal of Prisoners on Prisons, 23(2): 45-49. 
Ignatieff, Michael (1978) A Just Measure of Pain: The Penitentiary in the Industrial Revolution, New York: Pantheon Books.

Jackson, Michael (1983) Prisoners of Isolation: Solitary Confinement in Canada, Toronto: University of Toronto Press.

Jones, Forrest Lee (2014) “The Politics of Crowding in California Prisons", Journal of Prisoners on Prisons, 23(2): 64-70.

Lashuay, Jerry (2014) "The Child is Prey", Journal of Prisoners on Prisons, 23(2): X-X.

McCoy, Ted (2012) Hard Time: Reforming the Penitentiary in Nineteenth-Century Canada, Edmonton: AU Press.

McPherson, James M. (1988) Battle Cry of Freedom: The Civil War Era, New York: Oxford University Press.

Miller, J.R. (1996) Shingwauk's Vision: A History of Native Residential Schools, Toronto: University of Toronto Press.

Milloy, John S. (1999) A National Crime: The Canadian Government and the Residential School System, 1879 to 1986, Winnipeg: University of Manitoba Press.

Nagelsen, Susan and Charles Huckelbury (2014) "Evolving Standards of Decency: A Study of Political Perversity", Journal of Prisoners on Prisons, 23(2): 50-63.

Rotman, Edgardo (1995) "The Failure of Reform: United States, 1865-1965", The Oxford History of the Prison: The Practice of Imprisonment in Western Society, Toronto: Oxford University Press.

Shah, Neil (2014) "The Person I Am Now", Journal of Prisoners on Prisons, 23(2): 32-38.

Shook, Jarrod (2014) “Business as Usual”, Journal of Prisoners on Prisons, 23(2): 10-22. Taylor, Jon Marc (2014) "Turning Points: Coordinated Criminal Justice Reform in the Show-Me State", Journal of Prisoners on Prisons, 23(2): 84-90.

Vivar, Jose (2014) "The Truth About Provincial Prisons", Journal of Prisoners on Prisons, 23(2): 6-9.

Withrow, Oswald C. J. (1933) Shackling the Transgressor: An Indictment of the Canadian Penal System, Toronto: Thomas Nelson \& Sons.

\section{ABOUT THE AUTHORS}

Chris Clarkson is a Professor in the Department of History at Okanagan College. He conducts research on legal and social history, First Nations, as well as prisoners' experiences in the Canadian federal penal system documented in the penal press.

Melissa Munn is a Professor in the Department of Sociology at Okanagan College and is incoming Co-managing Editor of the Journal of Prisoners on Prisons. She also coordinates The Penal Press (penalpress.com), which is an open-access archive of newsletters written by prisoners and published in Canadian prisons since the 1950's. 